\title{
NON-GOVERNMENTAL ORGANIZATIONS IN POLAND: THEIR ROLE AND SOURCES OF FINANCING
}

Non-governmental organizations (NGOs) are institutions that belong most often to the social service sector, whose goals are to meet the specific needs of people that are not being met, or not being met adequately, by commercial organizations or state administrations. Such NGOs work to help citizens develop and to improve themselves and their life situations. This article presents an overview of the role played by NGOs in Poland and how they are funded.

Key words: sources of financing, NGO

JEL Code: L31, G38, I22

\section{Introduction}

In democratic countries there are three sectors (areas) of individual and institutional activity:

1. the first sector - activity aimed at generating profit, i.e. business, which includes production, services and trade;

2. the second sector - government sector - public activity of the government, including central and local administration;

3. the third sector - social activity which is not aimed to generate financial profit.

A non-governmental (social, non-profit) organization (NGO) is an institution whose purpose is to satisfy people's needs and provide help wherever the two other sectors are unable to reach or when their work is ineffective. One of the characteristic features of the third sector is the fact that the majority of its employees are volunteers ${ }^{1}$, who donate their time (and, at times, money) to realize the objectives of the organization ${ }^{2}$.

According to research that was carried out by Johns Hopkins University, Baltimore (which was conducted in Poland, as well), characteristic features of an NGO were determined as follows:

- lasting and clear organizational structure,

- $\quad$ structure which is independent from public government,

- self-governance,

- voluntary character - membership and support are not obligatory,

\footnotetext{
${ }^{1}$ According to Statistics Poland, in 2018 the organizations from the non-profit sector had 3042.3 thousand volunteers and 614.7 thousand employees (173.4 thousand under employment contract and 441.2 thousand under civil law contract.) - data accessed on 20.04.2020.

${ }^{2}$ E. Leś, S. Nałęcz, J.J. Wygnański, S. Toepler, L. M. Salamon: Sektor Non-Profit w Polsce. Szkic do portretu. Johns Hopkins University, Instytut Studiów Politycznych PAN, Bank Informacji o Organizacjach Pozarządowych KLON, Warszawa 2000, p. 2.
} 
- non-profit objectives - the surplus of revenues over expenses is used to realize the objectives of an $\mathrm{NGO}^{3}$.

The article uses the desk research method - the results of secondary research conducted by Klon/Jawor Association and Statistics Poland (formerly known as Central Statistical Office) are presented and discussed.

The third sector is defined in both broad and narrow ways. The Polish Act on Public Benefit and Volunteer Work broadly defines which institutions are recognised as nongovernmental organizations, i.e. those which do not operate in order to generate profit and are not "public finance entities as specified in 27 August 2009 Public Finance Law or companies, research institutes, banks and commercial law companies, which are national or local legal entities" 4 . According to the mentioned definition, non-government institutions include associations, foundations, political parties, hunting associations, trade and employee unions, farmer associations, farmer wives associations, faith-based charities, community clubs and support groups. The narrow definition of an NGO used in everyday speech refers to associations (without the General Corps of Volunteer Firefighters, which possess a legal form of an association) and foundations.

According to the data collected in the REGON register of businesses and entities, at the end of 2018 in Poland there were about 143 thousand NGOs, including 117 thousand associations (with 17 thousand units of the General Corps of Volunteer Firefighters) and 26 thousand foundations 5 .

According to a survey conducted by Statistics Poland, in 2018 Poland had 88.1 thousand NGOs, including 69.1 thousand associations, 14.5 thousand foundations, 2.7 thousand business and professional self-governing bodies and 1.8 thousand faith-based institutions. Public benefit organizations ${ }^{6}$ (in Polish: organizacje pożytku publicznego ${ }^{7}$, OPP) constituted 9.3 thousand of all the institutions ${ }^{8}$.

\section{The origins of non-governmental organizations in the world}

Social activity whose purpose is to selflessly provide help to those in need is called philanthropy (from the Greek "philanthropos" $\varphi \imath \lambda \alpha ́ v \theta \rho \omega \pi \circ \varsigma$ - one who loves humanity). Charitable activity in Europe developed in the Middle Ages, mostly within the Catholic Church. Also, self-help initiatives were realized by the first professional organizations and mutual benefit societies.

\footnotetext{
${ }^{3}$ Ibid, p. 2.

${ }^{4}$ The Act of 24 April 2003 on Public Benefit and Volunteer Work, art. 3.2. (Dz.U. No 96, item 873, as amended)

5 B. Charycka, M. Gumkowska: Kondycja organizacji pozarządowych 2018. Wyd. Stowarzyszenie Klon/Jawor, Warszawa 2019, p. 9.

${ }^{6}$ Public benefit organizations are such non-government organizations and other entities which undertake public benefit activity and, having met requirements stipulated in the Act, have been granted a status of OPP. This status is connected with additional obligations for such organizations, but at the same time enables them to obtain $1 \%$ of tax deduction. This type of organization was created in 2003 by Polish legislation.

${ }^{7}$ More about OPP see: Parlińska A.: Odpis $1 \%$ podatku PIT jako mechanizm finansowania działalności organizacji pożytku publicznego, w: Wasilewski M., Mądra-Sawicka M.(red): Finanse w działalności gospodarczej - teoria i praktyka, Wyd. SGGW, Warszawa 2019, p. 113-121

${ }^{8}$ Activities of Associations and Similar Organizations, Foundations, Faith-based Charities, Business and Professional Associations in 2018 - preliminary results, Statistics Poland, 23.12.2019 (data accessed on 20.04.2020)
} 
The beginning of what is now known as NGOs in Europe dates back to the $19^{\text {th }}$ century, when new social groups, i.e. capitalists and labourers, emerged. The labourers started establishing associations, co-operatives and trade unions in order to fight for their rights since individuals became too insignificant to be effective on their own. It coincided with the emergence of political parties, which resulted in the idea of civil society and made it possible for individuals to take active part in public life. The formation and expansion of non-government organizations in 19th-century Europe was closely linked with political and social changes as well as the concepts and ideas which accompanied them ${ }^{9}$.

The end of World War II in Western Europe marked the rise of welfare states with strong statist tendencies. Governments of that time wanted to highlight the importance of the state as a body which complements and corrects the way the market works, mainly on the social plain. The 1970s saw a crisis of the welfare state, which led to a turn towards social organizations. Nowadays, all over the world NGOs are fundamental elements of contemporary societies. They work for the common $\operatorname{good}^{10}$.

\section{The origins of non-government organizations in Poland}

It is believed that mid- $19^{\text {th }}$ century marks the beginning of the emergence of nongovernment organizations in Poland (although the first private foundations could be traced back to the $12^{\text {th }}$ century). The major idea which drove Polish society at the time was the quest to regain national independence. The expansion of a variety of self-help forms, which occurred after 1918, was stifled by the outbreak of World War II. In the aftermath of the war many of the organizations were not re-established. This was due to the formation of the Polish People's Republic, whose government closed down or nationalized the existing organizations by means of restrictive administrative decisions, laws and propaganda. After the fall of the Polish People's Republic and the rise of the Third Polish Republic, the third sector started expanding. Some of the organisations previously closed by the government were reborn, and some of the nationalised entities became independent from the state (ZHP - The Polish Scouting and Guiding Association, or PCK - Polish Red Cross). The development of the non-profit sector in Poland was influenced by ideas and practices which came from countries with strong self-governance traditions (mostly from the USA). Also, foreign financial and material help (both on the private and state level) had an impact on the development and growth of non-government institutions ${ }^{11}$.

\section{The functions of non-government organizations}

Depending on the chosen criteria, there are numerous classifications of the functions of NGOs. The one created by Aleksander Kamiński reflects hierarchy based on human needs and lists the following functions:

- affiliative - based on the need to belong to a group,

\footnotetext{
${ }^{9}$ T. Schimanek: Organizacje Pozarządowe i Samorząd Terytorialny. Możliwości wspólnych działan. Instytut Spraw Publicznych, Warszawa 2000, p.6.

${ }^{10}$ Ibid, p. 7.

${ }^{11}$ Ibid, p. 7.
} 
- $\quad$ integrative - it is important for each individual to form a group and build social bonds,

- expressive - by co-creating groups, individuals develop their interest and realize their potential ${ }^{12}$.

Another classification of NGO functions is proposed by Irena Lepalczyk. The author differentiates the following functions:

- $\quad$ to support the social, biological and cultural development of a person;

- to prepare a person to perform social and professional roles (e.g. by gaining experience in managerial/organizational capacities);

- to popularise knowledge by promoting scientific achievements and shaping desirable behaviours;

- to improve people's lives by providing in-depth understanding and the chance to shape the world around them as well as finding new ways to tackle everyday life;

- $\quad$ to develop the idea of democracy ${ }^{13}$.

Numerous handbooks quote the classification of functions put forward by Małgorzata Załuska ${ }^{14}$, who divides them into two groups:

- connected with satisfying interests, dreams and ambitions of an engaged individual (which comprises the following functions: helping ${ }^{15}$, expressive ${ }^{16}$, affiliative $^{17}$ );

- connected with satisfying the needs of a community, e.g. a local function, or a particular faction (which comprises the following functions: integrative ${ }^{18}$, normalization $^{19}$, care and education ${ }^{20}$, lobby $^{21}$, socialising the state $\left.{ }^{22}\right)^{23}$.

\section{The scope of activity and geographical distribution of NGOs in Poland}

Every two years Statistics Poland conducts a survey concerning the non-profit sector in Poland. According to the latest preliminary data, in 2018 there were 88.1 thousand active NGOs. In comparison to 2016, the number decreased by 3.7 thousand (previously, each time the number of the organizations rose by 3-4 thousand). Most NGOs operate in the

\footnotetext{
${ }^{12}$ A. Kamiński: Funkcje pedagogiki społecznej. Państwowe Wydawnictwo Naukowe, Warszawa 1982, p. 155158 .

${ }^{13}$ J. Praska - Kruszyńska: Realizacja zadań państwa poprzez organizacje "non profit”. w: Państwo i rynek w gospodarce, PTE, Szczecin 2003, p. 83-84.

${ }_{14}^{14}$ M. Załuska: Organizacje pozarządowe w społeczeństwie obywatelskim. Interart, Warszawa 1996, p. 36-37.

${ }^{15}$ Self-help and charity.

${ }^{16}$ Self-development.

${ }^{17}$ The need to belong to a social group.

${ }^{18}$ Building social bonds.

${ }^{19}$ Adjusting social activity with legal requirements.

${ }^{20}$ Creating optimum conditions to enable development, helping to adjust living conditions and overcoming various deficiencies in psycho-somatic sphere.

${ }^{21}$ Defending fundamental social values.

${ }^{22}$ Implementing democratic ideas.

${ }^{23}$ G. Krupa: Czy tylko instytucje państwowe i programy rządowe? w: Prewencja i rehabilitacja, Zakład Ubezpieczeń Społecznych, Warszawa 2004, p. 15.
} 
Mazowieckie, Wielkopolskie and Małopolskie regions, while Opolskie, Lubuskie and Podlaskie regions present the lowest number of active NGOs (see Table 1).

Table 1. Active non-government organizations in Poland 2010-2018

\begin{tabular}{|c|c|c|c|c|c|c|c|c|c|c|}
\hline \multirow{2}{*}{ Region } & 2010 & 2012 & 2014 & 2016 & 2018 & 2010 & 2012 & 2014 & 2016 & 2018 \\
\hline & \multicolumn{5}{|c|}{ [thousand pcs] } & \multicolumn{5}{|c|}{$[\%]$} \\
\hline Poland - Total & 80.4 & 83.5 & 87.7 & 9.8 & 88.1 & 100,0 & 100,0 & 100,0 & 100,0 & 100 \\
\hline Dolnośląskie & 5.8 & 6.2 & 6.7 & 6.9 & 7.0 & 7,2 & 7,5 & 7,6 & 7,5 & 8,0 \\
\hline Kujawsko-Pomorskie & 4.1 & 4.2 & 4.1 & 4.4 & 4.4 & 5,1 & 5,0 & 4,6 & 4,8 & 5,0 \\
\hline Lubelskie & 5.2 & 4.9 & 5.1 & 5.5 & 5.0 & 6,4 & 5,9 & 5,8 & 6,0 & 5,7 \\
\hline Lubuskie & 2.0 & 2.3 & 2.3 & 2.6 & 2.4 & 2,5 & 2,7 & 2,6 & 2,8 & 2,8 \\
\hline Łódzkie & 5.2 & 5.5 & 5.7 & 5.7 & 5.5 & 6,4 & 6,6 & 6,4 & 6,2 & 6,3 \\
\hline Małopolskie & 7.3 & 7.4 & 8.2 & 8.8 & 8.7 & 9,1 & 8,9 & 9,3 & 9,6 & 9,8 \\
\hline Mazowieckie & 12.4 & 13.4 & 13.2 & 14.2 & 13.4 & 15,5 & 16,1 & 15,1 & 15,5 & 15,2 \\
\hline Opolskie & 2.1 & 2.3 & 2.5 & 2.3 & 2.3 & 2,6 & 2,7 & 2,8 & 2,5 & 2,6 \\
\hline Podkarpackie & 5.0 & 5.1 & 5.3 & 5.6 & 5.3 & 6,2 & 6,1 & 6,1 & 6,1 & 6,0 \\
\hline Podlaskie & 2.6 & 2.6 & 2.8 & 2.7 & 2.5 & 3,2 & 3,2 & 3,2 & 3,0 & 2,8 \\
\hline Pomorskie & 4.7 & 4.8 & 5.2 & 5.5 & 5.2 & 5,8 & 5,8 & 5,9 & 6,0 & 5,9 \\
\hline Śląskie & 7.0 & 7.0 & 7.9 & 8.2 & 7.9 & 8,7 & 8,4 & 9,0 & 8,9 & 8,9 \\
\hline Świętokrzyskie & 2.6 & 2.6 & 2.7 & 2.9 & 2.8 & 3,2 & 3,2 & 3,1 & 3,1 & 3,1 \\
\hline Warmińsko-Mazurskie & 3.2 & 3.2 & 3.5 & 3.3 & 3.4 & 4,0 & 3,8 & 4,0 & 3,6 & 3,9 \\
\hline Wielkopolskie & 8.0 & 8.4 & 8.7 & 9.2 & 8.7 & 10,0 & 10,1 & 10,0 & 10,1 & 9,9 \\
\hline Zachodniopomorskie & 3.2 & 3.5 & 3.7 & 3.9 & 3.6 & 4,0 & 4,1 & 4,3 & 4,3 & 4,1 \\
\hline
\end{tabular}

Source: author's compilation based on the data of Statistics Poland.

Table 2. Non-government organizations ranked according to their main field of activity in 2018 (data presented in \%)

\begin{tabular}{|l|r|}
\hline overall & 100,0 \\
\hline sports, tourism, recreation, hobbies & 29,1 \\
\hline rescue services & 16,1 \\
\hline social services & 7,5 \\
\hline culture and arts & 12,1 \\
\hline education and research & 10,3 \\
\hline health & 4,1 \\
\hline business and professional associations & 3,6 \\
\hline environment & 2,7 \\
\hline hunting & 2,9 \\
\hline employment assistance & 1,4 \\
\hline local development & 3,9 \\
\hline law, advocacy, civil rights, politics & 1,7 \\
\hline philanthropic intermediaries and voluntarism promotion & 1,4 \\
\hline other activities, including international and religious & 3,2 \\
\hline
\end{tabular}

Source: author's compilation based on the data of Statistics Poland. 
Considering the differences connected with the sizes of administrative regions and the level of urbanization, it may be observed that in the eastern part of the country there are fewer NGOs, whereas most are located in the west and north. The borderline between these areas reflects the former borders between the territories annexed as a result of $18^{\text {th }}$-century partitions of Poland.

According to the data collected by Statistics Poland, the main fields of activity of active NGOs are: sport, tourism, recreation and hobbies (29\%), while the least indicated field is for philanthropic intermediaries and voluntarism promotion as well as employment support programmes (1.4\% each). Detailed data is presented below in Table 2.

According to the research carried out in 2018 by the Klon/Jawor Association, the majority of associations and foundations (i.e. NGOs which conform to the narrow definition) operate in the field of sports, tourism, recreation and hobbies $-35 \%$, while only $6 \%$ work in the field of local development. The Klon/Jawor Association presented a slightly different classification of fields of activity. Detailed data is presented below in Table 3.

Table 3. Main fields of activity of associations and foundations in 2018 (data presented in \%)

\begin{tabular}{|l|r|}
\hline overall & 100,0 \\
\hline sports, tourism, recreation, hobbies & 35,0 \\
\hline culture and arts & 14,0 \\
\hline education and research & 13,0 \\
\hline health & 8,0 \\
\hline social services & 7,0 \\
\hline local development & 6,0 \\
\hline $\begin{array}{l}\text { other (environment and ecology, job market, research, national identity, law, advocacy, civil } \\
\text { rights, politics, employment assistance, rescue services, security, defence, international activity, } \\
\text { development assistance, religion, NGO support) }\end{array}$ & 17,0 \\
\hline
\end{tabular}

Source: author's compilation based on B. Charycka, M. Gumkowska: Kondycja organizacji pozarządowych 2018. Wyd. Stowarzyszenie Klon/Jawor, Warszawa 2019, p. 11.

Most often, the organizations aimed to benefit children and youth as well as local communities.

\section{Sources of financing of non-government institutions}

Sources of financing of $\mathrm{NGOs}^{24}$ include:

- donations (both financial and material) from individual donors as well as firms/companies,

- membership fees,

- $\quad$ subsidies assigned to specific tasks given by central or local administration assigned to those tasks,

- income from their own business activity,

- capital foundation subsidies and foreign resources,

${ }^{24}$ Za: L. Stecki: Fundacje część pierwsza, Wydawnictwo „Dom Organizatora”, Toruń 1996, p. 160; Szustek A.: Polski sektor społeczny. Oficyna Wydawnicza ASPRA-JR, Warszawa 2008, p. 44-60. 
- public money collections,

- sponsorship,

- grants,

- foreign financial resources (funds from the European Union as well as outside the EU),

- $1 \%$ tax deduction from personal income tax (refers to public benefit organizations),

- other: loans.

According to another survey carried out by the Klon/Jawor Association, the average yearly budget of an average NGO in 2017 was 28 thousand PLN and is comparable to the data from the previous survey of 2014, when it reached the amount of 27 thousand PLN. Considering overall economic changes (including the increase of salaries and expenses), the increase of the budget is small, which may indicate limited activity within the sector. According to the data from 2011, the yearly budget at that time was 18 thousand PLN, which means that the increase in 2014 was significant.

Since 2001, the structure of income in the non-government sector has practically remained unchanged. Most organizations reach income of 10-100 thousand PLN, while only a few have income which exceeds 1 million PLN. Detailed data is presented below in Table 4. It is worth noting that the incomes vary depending on the field of activity, years of operation or the geographical location of a given $\mathrm{NGO}^{25}$.

Table 4. The structure of income in the non-government sector

\begin{tabular}{|c|r|r|r|r|r|}
\hline \multirow{3}{*}{ Year } & \multicolumn{5}{|c|}{ The structure of income in non-government sector (\%) } \\
\cline { 2 - 6 } & up to 1.000 PLN & $\begin{array}{c}1.000-10.000 \\
\text { PLN }\end{array}$ & $\begin{array}{c}10.000-100.000 \\
\text { PLN }\end{array}$ & $\begin{array}{c}100.000- \\
1.000 .000 \text { PLN }\end{array}$ & $\begin{array}{c}\text { more than } \\
1.000 .000 \text { PLN }\end{array}$ \\
\hline 2001 & 15 & 27 & 36 & 18 & 5 \\
\hline 2003 & 22 & 26 & 31 & 17 & 4 \\
\hline 2005 & 20 & 30 & 30 & 17 & 4 \\
\hline 2007 & 18 & 24 & 36 & 16 & 6 \\
\hline 2009 & 17 & 25 & 37 & 21 & \\
\hline 2011 & 21 & 22 & 36 & 22 & 6 \\
\hline 2014 & 14 & 20 & 39 & 43 & 6 \\
\hline 2017 & 11 & 19 & & 217 & 6 \\
\hline
\end{tabular}

Source: author's compilation based on P. Adamiak, B. Charycka, M. Gumkowska: Kondycja sektora organizacji pozarządowych w Polsce 2015. Raport z badań, Stowarzyszenie Klon/Jawor, Warszawa 2016, p. 60. B. Charycka, M. Gumkowska: Kondycja organizacji pozarządowych 2018. Wyd. Stowarzyszenie Klon/Jawor, Warszawa 2019, p. 12.

The popularity of particular sources of financing of NGOs in Poland over the years is presented below in Table 5. The most common sources include membership fees, national public funding and donations from individuals, institutions or companies.

The popularity of particular sources of funding does not directly correspond with the amount of income obtained by NGOs from these sources. In 2017 proportions between particular forms of financing were as follows:

- national public resources (central and local) - 39\%,

- foreign public resources (from the EU and outside the EU) - 15\%,

${ }^{25}$ B. Charycka, M. Gumkowska, p. 38. 
- paid services $-15 \%$,

- individual and institutional philanthropy $-14 \%$,

- $1 \%$ tax deduction $-3,5 \%$,

- membership fees $-3 \%$,

- own assets $-2 \%$,

- support of other NGOs (national and foreign) $-2 \%$,

- bank interest, profits from endowments etc. $-0.5 \%$,

- other $-6 \%^{26}$.

Table 5. Main sources of financing of non-government organizations in Poland in years 2005-2017 (according to popularity).

\begin{tabular}{|c|c|c|c|c|c|c|c|c|}
\hline Year & $\begin{array}{l}\text { Mem } \\
\text { bersh } \\
\text { ip } \\
\text { fees }\end{array}$ & $\begin{array}{l}\text { National } \\
\text { public } \\
\text { funds }\end{array}$ & $\begin{array}{l}\text { Individual } \\
\text { and } \\
\text { institutional } \\
\text { philanthropy }\end{array}$ & $\begin{array}{c}1 \% \\
\text { tax } \\
\text { dedu } \\
\text { ction }\end{array}$ & $\begin{array}{l}\text { Foreign } \\
\text { public } \\
\text { funds }\end{array}$ & $\begin{array}{c}\text { Paid } \\
\text { services }\end{array}$ & $\begin{array}{l}\text { Own } \\
\text { assets }\end{array}$ & $\begin{array}{l}\text { Support } \\
\text { of other } \\
\text { NGOs }\end{array}$ \\
\hline & \multicolumn{8}{|c|}{$\%$} \\
\hline 2005 & 60 & 54 & 54 & 6 & 5 & 16 & 17 & 14 \\
\hline 2007 & 57 & 56 & 51 & 13 & 10 & 15 & 17 & 11 \\
\hline 2009 & 61 & 57 & 50 & 17 & 12 & 15 & 16 & 14 \\
\hline 2011 & 61 & 50 & 43 & 17 & 13 & 16 & 18 & 12 \\
\hline 2014 & 60 & 60 & 56 & 23 & 18 & 17 & 15 & 14 \\
\hline 2017 & 63 & 65 & 63 & 25 & 11 & 23 & 16 & 15 \\
\hline
\end{tabular}

Source: author's compilation based on P. Adamiak, B. Charycka, M. Gumkowska: Kondycja sektora organizacji pozarządowych w Polsce 2015. Raport z badań, Stowarzyszenie Klon/Jawor, Warszawa 2016, p. 66. B. Charycka, M. Gumkowska: Kondycja organizacji pozarządowych 2018. Wyd. Stowarzyszenie Klon/Jawor, Warszawa 2019, p. 12.

In comparison with the data from the previous survey (referring to 2014) the share of national public funds (mostly from the government) increased by $9 \%$, while the proportion of foreign public funds decreased by $10 \%$. There was also an increase in the income from paid services by $4 \%$, whereas a $1.5 \%$ decrease was noted in reference to $1 \%$ tax deduction. The proportion of membership fees did not change. It shows how much NGOs are dependent on national and foreign public funding, i.e. external financing, instead of relying on their own resources. It is dangerous since without obtaining public funds such NGOs may cease to exist. The Klon/Jawor Association noticed that in the first quarter of $2018,71 \%$ of surveyed associations and foundations guaranteed no more than a half of the budget required for their yearly activity.

The most popular source of financing (membership fees) has little significance in most NGOs (3-7\%). National public funds (from local or central administration, including the government) constitute as much as $40 \%$ of the budget every year. According to the survey, NGOs use foreign sources less often than local sources, which might be a mistake, as the former are able to provide higher amounts of income. Individual and institutional philanthropy secures $14-20 \%$ of the means needed for nonprofit organizations to operate.

When it comes to using public funding by NGOs, it is possible to notice isomorphism ${ }^{27}$ within the administration. The border between the sectors gets blurred,

${ }^{26}$ Ibid, p. 13. 
since despite employing a form of competition and contract, local government units precisely specify what has to be done with the sources from particular funding, which leaves no place for NGOs to make independent decisions. Blurry lines between the sectors make NGOs similar to administrative units ${ }^{28}$.

The major certain source of income for non-profit organizations are membership fees $^{29}$. Also, income generated by paid services provided by NGOs as well as grants from foreign non-government institutions play an important part in the NGO budget. On average, funds from local government sources constitute half of the planned budget. The amount of financial resources which come from other national and foreign public sources (although not used as much by the NGOs), provides more money than the income from local governments. Also, donations are becoming a more and more significant source. It is a welcome change, which might mean that the society recognizes the growing importance of the third sector. If the income from this source increased even higher, it would be possible to try to make the associations and foundations independent from local government sources.

It may be noticed that the structure of financing of NGOs differs from the hierarchy of the sources of financing created by Donaldson and finally developed by Myers. According to the mentioned theory, an institution first uses the internal sources of financing (mostly profit), and only then does it move on to the external ones ${ }^{30}$. It remains in accordance with the fact that NGOs are units which do not work to make profit.

The problem which impedes the functioning of the third sector is its instability and the irregularity of financing. The most important support comes from local governments and foreign sources and is usually granted to NGOs in the course of competitions. Nevertheless, they constitute a very unreliable source, as at the stage of budget planning there is no certainty that an organization will obtain them. It significantly limits the possibility to employ personnel, realize and secure the continuity of performed tasks and results in a lack of stability of the organization or problems with financing day-to-day activities.

\section{Summary}

Non-government organizations play an important role in a country. They are useful to local governments and the society as a whole; they are public trust organizations.

The specificity of non-government organization lies in the fact that when it comes to financial solutions, they are hybrid institutions: they possess the elements of business institutions as well as public ones.

\footnotetext{
${ }^{27}$ P.A. Frumkin, Institutional isomorphism and public sector organizations. Journal of Public Administration Research and Theory, 2004, 14/3, p. 283-307.

${ }^{28}$ S. Mazur, J.J. Wygnański: Jak zmieniają się relacje państwa z organizacjami trzeciego sektora? w: S. Mazur, A. Pacut (red.): System finansowania organizacji pozarządowych w Polsce, Wyd. Małopolska Szkoła Administracji Publicznej Uniwersytetu Ekonomicznego w Krakowie, Kraków, 2015, p. 18.

29 D. Roszkowska Hołysz: Funkcjonowanie organizacji pozarządowych w Polsce. w: Funkcjonowanie instytucji non-profit do norm i standardów Unii Europejskiej pod red. naukową M. Fic, Wydawnictwo „Maria”, Zielona Góra 2002, p. 37-38.

30 S.C. Myers: The Capital Structure Puzzle, Journal of Finance, vol. 39, no. 3, 1984, p. 575-592, www.nber.org/papers/w1393.pdf (dostęp 20.04.2020).
} 
What seems to be optimistic for NGOs is the fact that more and more sources of financing become available for them - e.g. new funds from the European Union, or the facilitation of $1 \%$ tax deduction transfer. Thanks to such changes more and more adults (including the unemployed) may participate in education free of charge, children and young people who take part in various trips may learn about their homeland and culture of specific regions, while people managing or assisting in a variety of projects can develop and realize their potential.

What is pessimistic, however, is that non-government organizations do not have steady income sources at a required level, which could provide them with stability to act and develop themselves. Obtaining the majority of resources through competitions and grants does not allow to feel certain about having the necessary amount in the budget and, therefore, function in the same way. The question is whether it is realistic in the current conditions to change this situation.

\section{Bibliography}

Adamiak P., Charycka B., Gumkowska M.: Kondycja sektora organizacji pozarządowych w Polsce 2015. Raport z badań, Stowarzyszenie Klon/Jawor, Warszawa 2016

Charycka B., Gumkowska M.: Kondycja organizacji pozarządowych 2018. Wyd. Stowarzyszenie Klon/Jawor, Warszawa 2019

Dane Głównego Urzędu Statystycznego - Bank Danych Lokalnych dostęp 20.04.2020 r.

Frumkin P.A.: Institutional isomorphism and public sector organizations. Journal of Public Administration Research and Theory, 2004, 14/3

Kamiński A.: Funkcje pedagogiki społecznej, Państwowe Wydawnictwo Naukowe, Warszawa 1982

Krupa G.: Czy tylko instytucje państwowe i programy rządowe?, w: Prewencja i rehabilitacja, Zakład Ubezpieczeń Społecznych, Warszawa 2004

Leś E., Nałęcz S., Wygnański J. J., Toepler S., Salamon L. M.: Sektor Non-Profit w Polsce. Szkic do portretu, The Johns Hopkins University, Instytut Studiów Politycznych PAN, Bank Informacji o Organizacjach Pozarzadowych KLON, Warszawa 2000

Mazur S., Wygnański J.J.: Jak zmieniają się relacje państwa z organizacjami trzeciego sektora? w: Mazur S., Pacut A. (red.): System finansowania organizacji pozarządowych w Polsce, Wyd. Małopolska Szkoła Administracji Publicznej Uniwersytetu Ekonomicznego w Krakowie, Kraków, 2015

Myers S.C.: The Capital Structure Puzzle, Journal of Finance, vol. 39, no. 3, 1984, www.nber.org/papers/w1393.pdf (dostęp 20.04.2020)

Parlińska A.: Odpis $1 \%$ podatku PIT jako mechanizm finansowania działalności organizacji pożytku publicznego, w: Wasilewski M., Mądra-Sawicka M.(red): Finanse w działalności gospodarczej - teoria i praktyka, Wyd. SGGW, Warszawa 2019

Praska - Kruszyńska J.: Realizacja zadań państwa poprzez organizacje "non profit", w: Państwo i rynek w gospodarce, PTE, Szczecin 2003

Roszkowska Hołysz D.: Funkcjonowanie organizacji pozarządowych w Polsce w: Funkcjonowanie instytucji non-profit do norm i standardów Unii Europejskiej pod red. naukową M. Fic, Wydawnictwo „Maria”, Zielona Góra 2002

Schimanek T.: Organizacje Pozarządowe i Samorząd Terytorialny. Możliwości wspólnych działań, Instytut Spraw Publicznych, Warszawa 2000

Stecki L.: Fundacje część pierwsza, Wydawnictwo „Dom Organizatora”, Toruń 1996

Szustek A.: Polski sektor społeczny, Oficyna Wydawnicza ASPRA-JR, Warszawa 2008 
Ustawa z dnia 24 kwietnia 2003 r. o działalności pożytku publicznego i wolontariacie, art. 3.2. (Dz. U. $2003 \mathrm{Nr} 96$ poz. 873, tekst jednolity z pózn. zm.)

Załuska M.: Organizacje pozarządowe w społeczeństwie obywatelskim, Interart, Warszawa 1996

\section{Organizacja pozarządowe w Polsce - rola i ich źródła finasowania}

\section{Streszczenie}

Organizacje pozarządowe to instytucje zaliczające się do sektora społecznego, potrafiącego zaspokoić specyficzne potrzeby ludzi, których nie zaspokajają organizacje komercyjne i administracja państwowa. NGOsy wychowują, pomagają rozwijać i samorealizować się obywatelom. Artykuł przedstawia rolę jaką odgrywają organizacje pozarządowe oraz w jaki sposób są finansowanie. W artykule wykorzystano metodę desk research - przedstawiono i omówiono wyniki badań wtórnych, przeprowadzonych przez Stowarzyszenie Klon/Jawor oraz Główny Urząd Statystyczny.

Słowa kluczowe: źródła finansowania, organizacje pozarządowe JEL Code: L31, G38, I22

Information about the author:

Dr Magdalena Dąbkowska-Dworniak

Uniwersytet Jana Kochanowskiego w Kielcach,

Filia w Piotrkowie Trybunalskim

e-mail: magdalena.dabkowska@ujk.edu.pl

ORCID: 0000-0001-8740-3790 